\title{
Antihyperlipidemic Effect of Solanum incanum on Alloxan Induced Diabetic Wistar Albino Rats
}

\section{Tsenum JL*}

Makurdi College of Sciences, Federal University of Agriculture, Abuja, Nigeria

\begin{abstract}
The effect of orally administered aqueous fruit extract of Solanum incanum on serum lipid profile of Wistar Albino rats were determined. Twelve male and female Wistar Albino rats were randomly assigned into four groups of three rats each, following acclimatization to laboratory and handling conditions. Diabetes was induced with a single dose of alloxan $(120 \mathrm{mg} / \mathrm{kg})$ body weight and plasma glucose was taken $72 \mathrm{~h}$ after induction to confirm diabetes. The normal control was not induced. Animals in group a (normal control) and B (diabetic) were administered $0.5 \mathrm{ml}$ of normal saline respectively. Group C was administered with $10 \mathrm{mg} / \mathrm{kg}$ weight of glibenclamide and group D was administered $500 \mathrm{mg} / \mathrm{kg}$ body weight of aqueous Solanum incanum extract. Extract administration lasted for fourteen days. Water and feeds were allowed ad libitum. After the two weeks treatment with the plant extract, blood samples were collected by cardiac puncture for lipid profile analysis by standard methods and enzyme kits. At the end of week two, the lipid profile of all groups were significantly different. The result on lipid profile showed that the extract treated group was significantly lower $(P>0.05)$ in TC, TAG and VLDL as compared to diabetic control but significantly higher $(P<0.05)$ in $\mathrm{HDL}$ and $\mathrm{LDL}$ as compared to diabetic control. The glibenclamide treated group was significantly lower $(P>0.05)$ in TAG, I-ID L, and VLDL as compared to the diabetic control but significantly higher $(P<0.05)$ in TC and LDL as compared to diabetic control. However, the extract was observed to have a high significant level of TC, TG, HDL, LDL and VLDL compared to the Normal control. Result on weight showed a significant difference at week and week 2. Antihypercholesterolemic and antihypertigliceridemic effect were observed in this result. Results suggest that Solanum incanum has hypolipidemic effect and therefore makes it beneficial in the dietary management of cardiovascular complications associated with diabetes and that its consumptions are safe for humans.
\end{abstract}

Keywords: Diabetes; Hyperlipidemia; Solanum incanum; Glibenclamide; Alloxan monohydrate

\section{Introduction}

\section{Background of the study}

Diabetes mellitus (DM) is a metabolic disorder resulting from a defect in insulin secretion, insulin action, or both. Insulin deficiency in tum leads to chronic hyperglycemia with disturbances of carbohydrates, fat and protein metabolism [1]. Experimental diabetes in animals provided a considerable insight into the physiologic and biochemical derangements of the diabetes state. Studies have shown that individuals with diabetes have a higher incidence of liver and kidney function abnormalities, as well as formation of free radicals due to glucose oxidative, non-enzymatic glycosylation of proteins and subsequent oxidative degradation of glycated proteins, leading to a decline in antioxidant defense mechanisms and damage of cellular organelles and enzymes, increased lipid peroxidation and development of insulin [2]. It is a long term chronic condition that causes high blood sugar levels. It is one of the common metabolic disorders with micro and macrovascular complications that results in significant morbidity and mortality. Diabetes mellitus results from defects in insulin secretion, insulin sensitivity or both and include a group of metabolic disorders characterized by hyperglycemia and abnormalities in carbohydrates, fats and protein metabolism [3]. It is considered as one of the five leading causes of death in the world [4,5]. It is recognized as a global epidemic by the world health organization [6].

Diabetes mellitus occur throughout the world and research has shown that its prevalence was higher and common in developed countries than in the developing countries in the mid '90s [7]. Globally as of 2010, an estimated 285 million people had diabetes [8]. In 2013, according to International Diabetes Federation, an estimated 381 million people had diabetes [9]. Its prevalence is increasing rapidly and by 2030 , this number is estimated to almost double [10]. It is worry some to note that the major part of this numerical increase is expected to occur in developing countries where there is rapid urbanization, nutrition transition and increasingly sedentary lifestyles [11]. Patients with uncontrolled diabetes mellitus usually experience heart failure which indicates that hyperglycemia maybe responsible for the disease [12]. Hyperglycemia produces symptoms of polyuria, polydipsia and polyphagia. It is also associated with long term damage and failure of various organs such as eyes, kidney, liver, nerves, heart and blood vessels. Diabetes mellitus is associated with alteration in the plasma lipid and lipoprotein profile [13].

Current interest in the search for appropriate agents in the management of diabetes is therefore focused on traditional medicinal plants. Natural herbs are plants or plants part used for its scent, flavor or therapeutic properties. Herbal medicines maintain and improve health and they do not go through the testing that chemotherapeutic agents go through. Secondly, the plants by means of secondary metabolism, contain a variety of phytochemical ingredients that are thought to act on a variety of targets by various modes and mechanisms [14] as expected from its pathogenicity. Unlike chemotherapeutic agents, however, herbal remedies have been reported to be nontoxic, accessible

*Corresponding author: Joseph Luper Tsenum, Makurdi College of Sciences Federal University of Agriculture, Abuja, Nigeria, Tel: +2348160457248/ +2347058245055; Fax: 08160457248; E-mail: tsenumjosephluper@gmail.com

Received April 17, 2018; Accepted April 25, 2018; Published April 30, 2018

Citation: Tsenum JL (2018) Antihyperlipidemic Effect of Solanum incanum on Alloxan Induced Diabetic Wistar Albino Rats. Cardiovasc Pharm Open Access 7: 239. doi: $10.4172 / 2329-6607.1000239$

Copyright: (c) 2018 Tsenum JL. This is an open-access article distributed under the terms of the Creative Commons Attribution License, which permits unrestricted use, distribution, and reproduction in any medium, provided the original author and source are credited. 
and affordable and represent the first line of treatment available for many of the world's population $[15,16]$. The interest in the use of herbal remedies could be attributed to the drawbacks in the use of the chemotherapeutic agents such as cost, hypoglycemia, weight gain, gastrointestinal disturbances and liver toxicity [17].

However of the several traditional plants reported for the treatment of diabetes [18-20] scientific interest and research reports have concentrated mostly on the screening of plants for blood sugar lowering effect to the neglect of investigation into their site and mechanism of action and for possible development into antidiabetic drugs and antihyperlipidemic drugs.

In indigenous medicine, Solanum incanum has a wide range of utilization from weight reduction to treatment of several ailments including asthma, allergic disease, swollen joint pains, gastroesophageal reflux disease, constipation and dyspepsia. Scientific studies have supported the traditional use of this plant (Solanum incanum) in treating inflammation, asthma, glaucoma, diabetes and excessive weight gain [21]. The fruit is easily eaten as snack and it has been reported to be high in phytochemicals like Saponins, flavonoids, tannins and ascorbic acid [22]. Studies have shown that dyslipidemia associated non-communicable diseases like diabetes and obesity are on the increase in the developing world and a continuous study is required to identify indigenous plant materials that can mitigate against, or at least useful in the management of dyslipidemia [23-25]. Hence, the investigation of the influence of the consumption of Solanum incanum fruit on plasina lipid profile is of interest.

\section{Materials and Methods}

\section{Materials}

Materials/Apparatus: Fresh fruits of Solanum incanum, mortar and pestle, distilled water, glass bottle, ASTM 60 mesh, water bath, thermometer, Accu-chek glucometer, test strips, cages for rats, weighing balance, micro pipette, centrifuge, dessicator, spectrophotometer, glucose, 15 male and female albino rats of wistar strain, were used for this study.

Chemicals/Reagents utilized: Alloxan monohydrate (St. Louis, MO., USA), Glibenclamide (Daonil; Aventis Pharma. Ltd., India), Cholesterol reagent (Teco Diagnostics., USA), Triglyceride GPO reagent (Teco Diagnostics., USA) and HDL Cholesterol reagent (Agappe Diagnostics., Switzerland) were obtained from a distribution company in Makurdi.

Location of the study: The entire study was carried out in Federal University of Agriculture Makurdi, Benue State. The plant extraction, acclimatization of rats, induction of diabetes, treatment of diabetes, biochemical analysis and statistical analysis were all carried out in the aforementioned institution.

Plant sample collection: Fresh fruits of Solanum incanum (bitter garden egg) were obtained from the university research farm of the Federal University of Agriculture, Makurdi after which it was washed and dried for further use.

Experimental animals: Healthy adult male and female wistar albino rats weighing about 140-180 g were obtained from the College of Health Sciences Animal House, Benue State University Makurdi and allowed to acclimatize for 30 days. The animals were housed in standard well ventilated cages at room temperature and provided with water and top feed growers pellets rat diet and water (Figure 1).

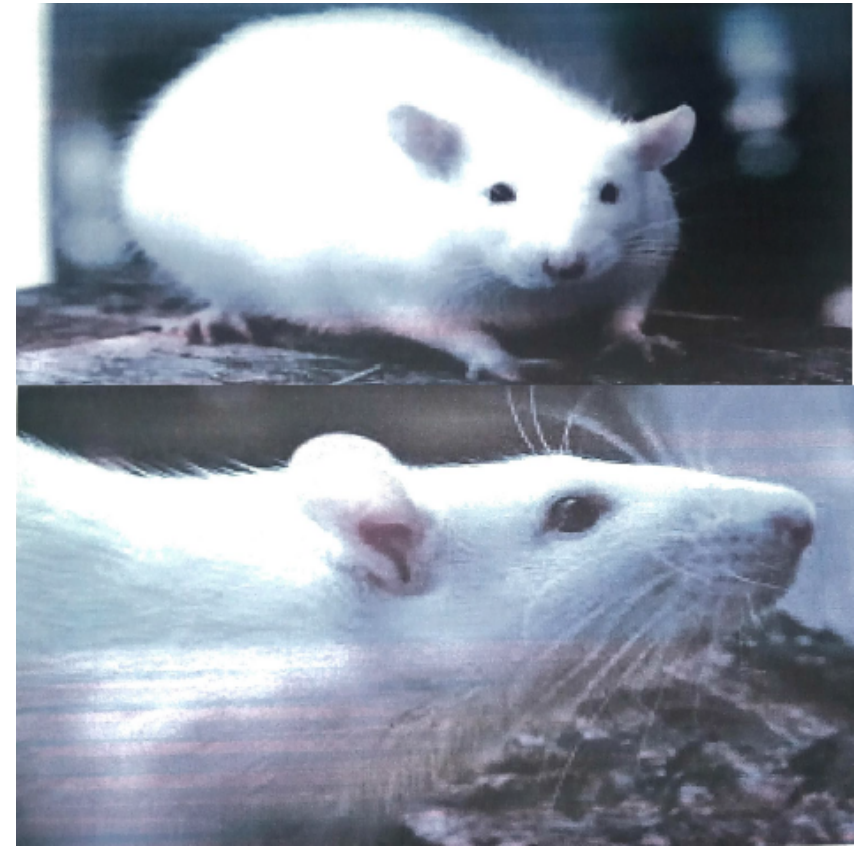

Figure 1: Wistar Albino Rats.

\section{Methodology}

Experimental procedures for plant sample preparation: The collected fresh fruits of Solanum incanum were washed and sliced into small pieces, partially sundried for one week to extract the powdered form of the plant after which it was shade dried for another one week. The dried pieces were then pounded gently into powder using mortar and pestle while the extract was then prepared from the powder [2635].

Experimental procedures for aqueous extract preparation: 200 $\mathrm{g}$ of the powder was dissolved in $1600 \mathrm{ml}$ of distilled water in a glass bottle for a period of 48 hours with intermittent vigorous shaking. The solution was filtered with ASTM 60 mesh size while the filtrate was then collected and evaporated at $45^{\circ} \mathrm{C}$ using water bath. The dried concentrate (extract) was then stored in a sealed transparent bottle for subsequent use.

Experimental procedures for diabetes induction: Diabetes was induced by a single intraperitoneal injection of alloxan monohydrate (120 mg/kg body weight) after 18 hours fast [26] while 5\% glucose solution was administered orally so as to prevent the drug induced hypoglycemic effect of alloxan [27]. After 72 hours of alloxan injection, blood samples were collected by tail snip method to determine the blood glucose concentrations to confirm the development of diabetes mellitus. Rats with fasting blood glucose concentration of greater than $126 \mathrm{mg} / \mathrm{dl}$ [28] were considered hyperglycemic and were selected for the study [36-58].

Experimental design: The animals were randomly divided into four groups each containing three rats while each rat was marked using black stain; Group A received a mark on the head, Group B received a mark on the body, Group C received a mark on the tail, while Group $\mathrm{D}$ received a mark on both tail and ear. Each cage was identified by a label comprising the cage number, the dose of alloxan/treatment to be received by the animal, and the numbers and weight of the animals in each cage. 


\section{Non-Diabetic group}

Group A: (NORMAL CONTROL/non-diabetic rats): Were administered $0.5 \mathrm{ml}$ normal saline only. On the $7^{\text {th }}$ and 14 th days of treatment, the blood glucose levels of the rats were determined using accu-chek glucometer, the animals were then weighed to determine the effect of the plant extract on their body weights. The results obtained were then expressed in $\mathrm{g}$ of body weight and $\mathrm{mg} / \mathrm{d} 1$ of blood respectively.

\section{Diabetic groups:}

Group B: (NEGATIVE CONTROL/untreated diabetic rats): Served as diabetic control; receiving $0.5 \mathrm{ml}$ normal saline/day/rat.

Group C: (POSITIVE CONTROL/diabetic rats): Were administered Glibenclamide (10 $\mathrm{mg} / \mathrm{kg}$ b.wt./day) in $0.5 \mathrm{ml}$ normal saline as a fine aqueous suspension orally.

Group D: (TEST CONTROL / diabetic rats): Were administered aqueous extract of Solanum incanum (500 mg/kg b.wt./day) as a fine aqueous suspension orally in $0.5 \mathrm{ml}$ normal saline [59-77].

Percentage yield of extract: The percentage yield of the plant sample can be calculated using the formula below:

Weight of dried extract/weight of original sample x 100

Weight of dried sample $=9.53 \mathrm{~g}$, weight of original sample $=200 \mathrm{~g}$

$9.53 / 200 \times 100=4.765 \%$

Collection and treatment of sample: The extracts were reconstituting in saline water and administered orally on daily basis. The extract group was treated with $500 \mathrm{mg} / \mathrm{kg}$, while the diabetic control and the normal control were given $0.5 \mathrm{ml}$ of saline water for a period of 14 days. At the end of 14 days, the fasting blood glucose level of all the animals were taken, the animals were weight and the animals were anaesthetized using chloroform and bled by cardiac puncture 24 $\mathrm{h}$ after the last treatment. The blood sample was collected in specimen bottles, allowed to clot and the serum separated by centrifugation for $10 \mathrm{~min}$, and then stored at $37^{\circ} \mathrm{C}$ and subjected to biochemical analysis [78-89].

\section{Lipid profile Test Procedures}

Determination of serum total cholesterol: The principle: The enzymatic reaction sequence employed in the assay of cholesterol is as follows

\section{Cholesterol Esters C. Esterase Cholesterol + Patty acid}

Cholesterol $+\mathrm{O}_{2}$ C. Esterase Cholesterol-3-one $+\mathrm{H}_{2} \mathrm{O}_{2}$ $+2 \mathrm{HO}_{2}$

$2 \mathrm{H}_{2} \mathrm{O}_{2}+4$-Aminoantipyrinc+ p-HBS H. Peroxidase Quinonemine

\section{(Red dye)}

Cholesterol esters then hydrolyses to produce cholesterol. Hydrogen peroxide is then produced from the oxidation of cholesterol oxidase. In a coupled reaction catalysed by peroxidase, quinoneimine dye colored red is formed from 4- aminantipyrine, p-HBS and hydrogen peroxide. The absorption at $520 \mathrm{~nm}$ of the solution of this dye is proportional to the concentration of cholesterol in the sample. The routine procedures include:

Reagent were prepared according to instructions via Label. Test tubes were labelled: blank, standard, control, rat's blood sample etc. $1.0 \mathrm{ml}$ of reagent was pipetted to all test tubes and pre-warmed at $37^{\circ} \mathrm{C}$ for at least two minutes. $0.01 \mathrm{ml}(10 \mu \mathrm{l})$ of sample was added to respective tubes, properly mixed, and returned to $37^{\circ} \mathrm{C}$. All tubes were incubated at $37^{\circ} \mathrm{C}$ for ten minutes. The spectrophotometer was zeroed with the blank reagent at $520 \mathrm{~nm}$. Absorbance of all tubes were read and recorded [90-105].

Determination of triacylglyceride (TAG): The enzymatic reaction sequence employed in the assay of TAG is as follow:

\section{TAG Lipase Glycerol + Fatty Acids}

Glycerol+ ATP Glycerol Kinase Glycerol -1-phosphate + ADP

Glycerol-I-phosphate $+\mathrm{O}_{2}$ GIP Oxidase DAP $+\mathrm{H}_{2} \mathrm{O}_{2}$

$\mathrm{H}_{2} \mathrm{O}_{2}+4 \mathrm{AAP}+$ DHBS Poxidase Quinoneimine Dye $+2 \mathrm{H}_{2} \mathrm{O}$

The procedure invqlves hydrolysis of TAG by lipase. The glycerol concentration is then determined by enzymatic assay coupled with Trinder reaction that terminates in the formation of quinoneimine dye. The amount of the dye formed, determined by its absorption at $520 \mathrm{~nm}$, is directly proportional to the concentration of TAG in the samples. The routine procedures include [106-110].

The triacyglyceride reagent was reconstituted according to instructions via label. Tubes were labelled: blank, standard, control, rat's blood sample etc. $1.0 \mathrm{ml}$ of reagent was pipetted to all tubes and pre-warmed at $37^{\circ} \mathrm{C}$ for 4 minutes. $0.01 \mathrm{ml}(10 \mu \mathrm{l})$ of sample was to respective tubes, properly mixed and returned to $37^{\circ} \mathrm{C}$. All tubes were incubated at $37^{\circ} \mathrm{C}$ for five (5) minutes. Spectrophotometer was zeroed with the reagent blank at $520 \mathrm{~nm}$. The absorbance of all tubes was read and recorded (Teco Diagnostics, 2012).

Determination of direct HDL cholesterol (HDLc): The principles of biochemical analysis include: The chylomicrons, very low density lipoproteins (VLDL) and low density lipoproteins (LDL) of serum are precipitated by phosphotugstic acid and magnesium ions. After centrifugation, High density lipoproteins (HDL) are in the supernatant. HDL content of the supernatant is measured by an enzymatic method. The routine procedures include [111-116].

Precipitation: The High density lipoprotein reagent was reconstituted according to instructions via label. Tubes were labeled: blank, standard, control, rat's blood sample etc. $300 \mu \mathrm{l}$ of sample and 300 $\mu \mathrm{l}$ of HDL reagent was pipetted into a test tube, it was properly mixed and allowed to stand for $10 \mathrm{~min}$ at room temperature, it was mixed again and centrifuged for $10 \mathrm{~min}$, at $4000 \mathrm{rpm}$. After centrifugation, the clear supernatant was separated from the precipitate within 1 hour and the HDL cholesterol concentration was determined using the cholesterol reagent.

The tubes were labeled: blank, standard, control, rat's blood sample, $1000 \mu \mathrm{l}$ of cholesterol reagent was pipetted into each tube except the tube labeled standard, $50 \mu$ of HDL supernatant was pipetted into the test tube labeled standard, it was mixed and incubated for five minutes at $37^{\circ} \mathrm{C}$. The absorbance of the standard and sample was measured against the reagent blank.

Determination of VLDL and LDL cholesterol by calculation: The very low density lipoprotein was obtained by calculation using the formula: TG/5 (mg/di). While Low density lipoprotein was calculated using the formula:

$$
\mathrm{LDL}=\mathrm{TC}-\mathrm{TG} / 5 \text { (In mg/dl) [29]. }
$$

Biochemical analysis: The serum levels of total cholesterol and triglyceride and HDL were determined by Teco diagnostic, (2012) while the serum levels of LDL was measured according to the protocol of Friedewald [29]. 
Statistical analysis: Data was expressed as mean \pm standard deviation. Comparative analyses between and amongst variables were done using analysis of variance (ANOVA). A post hoc comparison (LSD) test was performed to further ascertain significant differences between means. Statistical significance was set at $\mathrm{P}<0.05$. All statistics were done using SPSS (Table 1).

\section{Results}

\section{Effect of Solanum incanum on plasma glucose level of wistar albino rats}

Mean values in the same column not followed by the same letter are significantly different at 0.05 level of significance. ${ }^{\star}$ Mean values of $\mathrm{C}$ (glibenclanlide treated) and D (plant extract treated) are significantly different at 0.05 level of significance from those of B (diabetic control). $\neq$ Mean values of $C$ (glibenclamide treated) are significantly different at 0.05 level of significance from those of D (plant extract treated). Mean values of B (diabetic control), C (glibenclamide treated) and D (plant extract treated) are significantly different at 0.05 level of significance from those of A (normal control) (Figures 2 and 3).

Key: WAT: Weeks after treatment; A: Normal control; B: Diabetic control; C: Glibenclamide treated; D: Solanum incanum treated.

\section{Effect of Solanum incanum on body weight of wistar albino rats}

Mean values in the same column not followed by the same letter are significantly different at 0.05 level of significance. ${ }^{*}$ Mean values of $\mathrm{C}$ (glibenclamide treated) and D (plant extract treated) are significantly different at 0.05 level of significance from those of B (diabetic control). $\ddagger$ Mean values of $C$ (glibenclamide treated) are significantly different at 0.05 level of significance from those of $\mathrm{D}$ (plant extract treated). ¥Mean values of B (diabetic control), C (glibenclamide treated) and D (plant

\begin{tabular}{|c|c|c|c|c|}
\hline Treatment & $\begin{array}{l}\text { Before } \\
\text { Induction } \\
\text { (mg/dl) }\end{array}$ & $\begin{array}{l}72 \text { Hours After } \\
\text { Induction (mg/ } \\
\text { dl) }\end{array}$ & 1 WAT (mg/dl) & 2 WAT (mg/dl) \\
\hline A & $75.67 \pm 3.06^{a}$ & $114.00 \pm 10.82^{\mathrm{a}}$ & $94.00 \pm 3.61^{c}$ & $81.67 \pm 19.35^{b}$ \\
\hline$B$ & $78.66 \pm 4.04^{a}$ & $137.67 \pm 10.07^{\mathrm{a}}$ & $110.67 \pm 7.02^{\mathrm{af}}$ & $82.67 \pm 3.79^{b}$ \\
\hline C & $73.33 \pm 2.08^{a}$ & $134.67 \pm 16.56^{\mathrm{a}}$ & $106.00 \pm 2.00^{\mathrm{a} \neq}$ & $90.67 \pm 17.47 a^{* \dagger \neq}$ \\
\hline D & $73.67 \pm 3.26^{a}$ & $133.67 \pm 15.56^{\mathrm{a}}$ & $102.00 \pm 1.00^{\mathrm{a}}$ & $78.67 \pm 6.11^{b}$ \\
\hline LSD (0.05) & 0.154 & 0.982 & 0.006 & 0.737 \\
\hline
\end{tabular}

Values are expressed as Mean $\pm S D, n=4$.

Table 1: Effect of Solanum incanum on fasting plasma glucose level of Wistar Albino Rats.

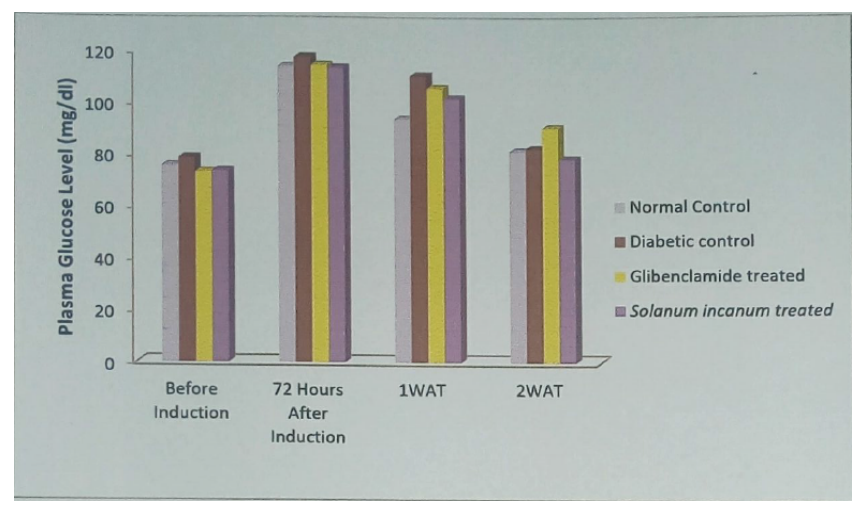

Figure 2: Effect of Solanum Incanum on plasma glucose level of Wistar Albino Rats. extract treated) are significantly different at 0.05 level of significance from those of A (normal control) (Table 2 and Figures 4, 5).

Key: WAT: Weeks after Treatment; A: Normal control; B: Diabetic control; C: Glibenclamide treated; D: Solanum incanum treated.

\section{Effect of Solanum incanum on lipid profile of wistar albino rats}

Mean values in the same column not followed by the same letter are significantly different at 0.05 level of significance. ${ }^{*}$ Mean values of $C$ (glibenclarnide treated) and D (plant extract treated) are significantly different at 0.05 level of significance from those of B (diabetic control). $\ddagger$ Mean values of $C$ (glibenclamide treated) are significantly different at 0.05 level of significance from those of $\mathrm{D}$ (plant extract treated) values of B (diabetic control), C (glibenclamide treated) and D (plant extract treated) are significantly different at 0.05 level of significance from those of A (normal control) (Table 3 and Figure 6).

Key A: Normal control; B: Diabetic control; C: Glibenclarnide treated; D: Solanum incanum treated; TC: Total Cholesterol; TAG; Triacylglycerol; HDL: High Density Lipoproteins; LDL: Low density Lipoproteins; VLDL: Very Low Density Lipoproteins.

\section{Discussion}

Dyslipidemia is a metabolic disorder that constitutes a crucial risk factor of atherosclerosis and cardiovascular diseases. Diabetes progresses with alteration in the serum lipid profile which can result in dyslipidemia [30]. It has been demonstrated that insulin deficiency in diabetes mellitus le ads to accumulation of lipids such as total cholesterol and triglycerides in diabetic patients (Sharma et al.). In uncontrolled diabetes mellitus, increase in total cholesterol, triglyceride, LDL, VLDL cholesterol with decrease in HDL cholesterol which contributes to coronary artery disease have been observed [31].

The relationship between diabetes and hyperlipidemia is a well recognised phenomenon. The increased risk of coronary artery

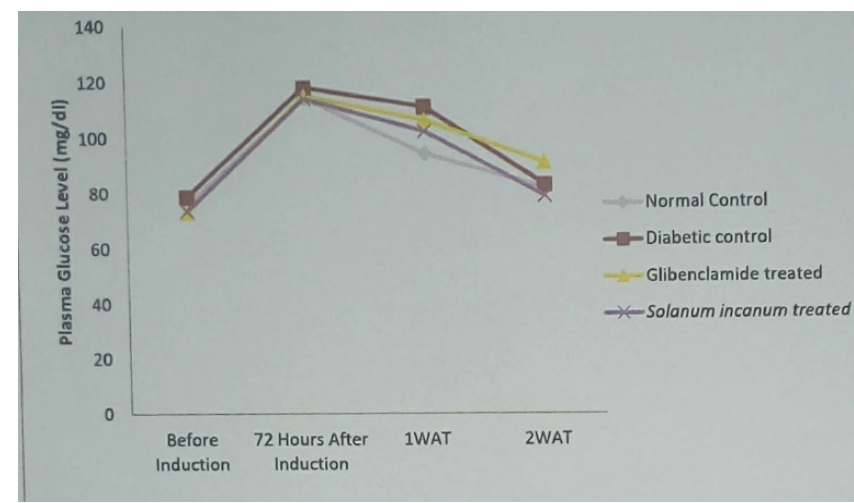

Figure 3: Effect of Solanum incanum on plasma glucose level of Wistar Albino Rats.

\begin{tabular}{|c|c|c|}
\hline Treatment & 1 WAT (g) & 2 WAT (g) \\
\hline A & $137.00 \pm 24.19^{\mathrm{c}}$ & $140.33 \pm 8.50^{\mathrm{d}}$ \\
\hline B & $200.00 \pm 6.25^{\mathrm{b}}$ & $199.67 \pm 24.68^{\mathrm{b} \neq}$ \\
\hline C & $200.00 \pm 20.88^{\mathrm{b} \neq}$ & $193.00 \pm 19.08^{\mathrm{c}^{*} \neq}$ \\
\hline D & $205.00 \pm 17.52^{\mathrm{a}^{\star} \neq}$ & $218.00 \pm 13.08^{\mathrm{a}^{*} \neq}$ \\
\hline LSD $(0.05)$ & 0.06 & 0.03 \\
\hline
\end{tabular}

Values are expressed as Mean $\pm S D, n=4$.

Table 2: Effect of Solanum incanum on body weight of Wistar Albino Rats (g) 
disease in subjects with diabetes can be partially explained by the lipoprotein abnormalities associated with diabetes mellitus [32]. Hypercholesterolemia and hypertriglyceridemia are independent major risk factors that alone or together can accelerate the development of coronary artery disease [33].

Derangements in lipid metabolism which result in hyperlipidemia have been reported in the pathology of various human diseases such as diabetes and atherosclerosis [34]. It has been well established that reduction of total cholesterol or low density lipoprotein cholesterol (LDLc) could lead to decreased risk of atherosclerosis and coronary heart diseases [35].

When rats are injected with alloxan, they provide an animal model of insulin dependent diabetes mellitus [36]. The intraperitoneally administration of alloxan $(120 \mathrm{mg} / \mathrm{kg} . \mathrm{wt})$ selectively destroys the insulin producing beta-cells of the Islet of Langerhans in the pancrease [37]. In this present study, there was severe hyperglycemia in the experimental rats as a result of alloxan induction in albino rats.

The result of the present findings demonstrated that aqueous fruit extract of Solanum incanum induced a significant reduction $(\mathrm{P}>0.05)$

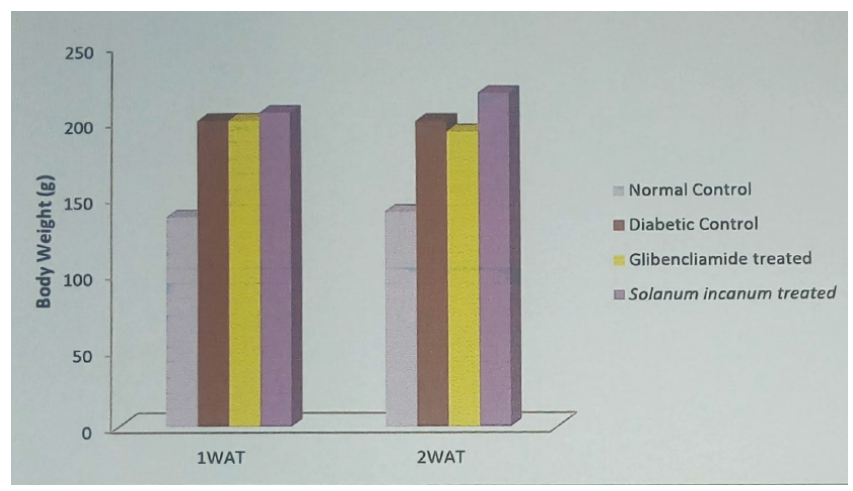

Figure 4: Effect of Solanum incanum on body weight of Wistar Albino Rats.

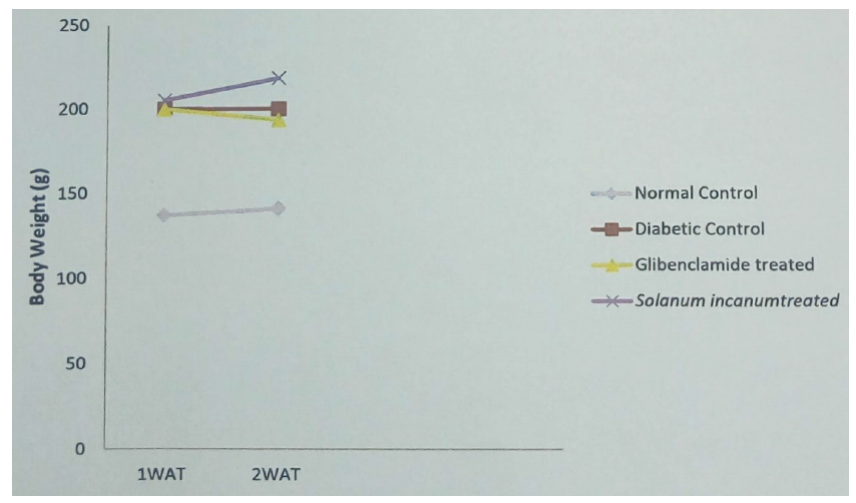

Figure 5: Effect of Solanum incanum on body weight of Wistar Albino rats. in the lipid profile in alloxan-induced diabetic Wistar Albino rats after 1st and 2nd weeks of treatment as shown in Table 4, suggesting that the extract may be used to reduce heart failure a view shared by Okutan [12]. It is thought that this reduction in lipid profile level by the plant extract may be related to its phytochemical constituent such as Saponins, flavonoids and phenolic compounds [38], which confers hypolipidemic activity on Solanum incanum.

My present findings indicated that lipid profile total cholesterol (TC), Triglycerol (TAG), and Very Low Density Lipoprotein (VLDL) was significantly decreased $(\mathrm{P}>0.05)$ in diabetic rats treated with Solanum incanum extract as compared to the non-treated group but significantly increased $(\mathrm{P}<0.05)$ in Density Lipoprotein $(\mathrm{HDL})$ and Low Density Lipoprotein as compared to the diabetic group as shown in Table 4.

These findings support the work of Chinedu 2013 [39] which demonstrated that Solanum aethiopicum, a member of the Solanaceae family decreased the raised serum total cholesterol (TC) levels in treated rats. The only contradicting evidence between my findings and that of Chinedu 2013 [39] is that while LDL increased $(\mathrm{P}<0.05)$ in my work, Chinedu [39] showed a reduction in LDL. An increase in low density lipoprotein (LDL) may be due to increased body Weight in the rats treated with the extract, as initial approaches to lowering the levels of lipids in subjects with diabetes should include glycemic control, diet weight loss and exercise [32]. These findings also agrees with the work of Arulmozhi [40] who reported that Solanum nigrum, a member of the Solanaceae family increased low density lipoprotein (LDL) levels. While HDL increased $(\mathrm{P}<0.05)$ in my work, Arulmozhi [40] reported a reduction in HDL. Also, while TC, VLDL and TAG reduced $(\mathrm{P}>0.05)$ in my work, Arulmozhi [40] reported an increase in TC, VLDL and TAG.

The glibenclamide treated group was significantly lower $(\mathrm{P}>0.05)$ in TAG, HD, L and VLDL as compared to the diabetic control but significantly higher $(\mathrm{P}<0.05)$ in $\mathrm{TC}$ and $\mathrm{LDL}$ as compared to diabetic control as shown in Table 4 . The extract was significantly lower $(\mathrm{P}>0.05)$ in TC and LDL as compared to glibenclamide treated group but significantly higher $(\mathrm{P}<0.05)$ in TAG, HDL and VLDL as compared to glibenclamide treated group as shown in Table 4 . The glibenclamide treated group was significantly lower $(\mathrm{P}>0.05)$ in TAG, HDL and VLDL as compared to the extract treated group but significantly higher $(\mathrm{P}<0.05)$ in TC and LDL as compared to extract treated group as shown in Table 4. However, the extract and the standard drug was observed to have high significant level of TC, TG, HDL, LDL and VLDL compared to the Normal control as shown in Table 4.

A reduction in triglycerol level may be due to decreased lipogenesis increased lipolytic activity by inhibition of hormone sensitive lipase or the lipidemic enzymes or activation of some serum lipase as have been proposed for some anti-diabetic plants [41,42], exhibiting hypoglycemic activity as observed in this present study. The extract showed a significant decrease $(\mathrm{P}>0.05)$ on the plasma glucose level as shown in Table 4. Loss of body weight is a major consequence of

\begin{tabular}{|c|c|c|c|c|c|}
\hline Treatment & $\mathrm{TC}(\mathrm{mg} / \mathrm{dl})$ & TAG (mg/dl) & HDL (mg/dl) & LDL (mg/dl) & VLDL (mg/dl) \\
\hline A & $140.37 \pm 26.65^{d}$ & $100.50 \pm 26.96^{d}$ & $44.43 \pm 4.33^{b}$ & $111.33 \pm 21.57^{d}$ & $20.10 \pm 5.39^{c}$ \\
\hline B & $309.80 \pm 39.17^{\mathrm{b} \neq}$ & $179.87 \pm 29.50^{\mathrm{a} \neq}$ & $47.07 \pm 7.69^{b}$ & $225.77 \pm 58.17^{\mathrm{c} \ddagger}$ & $35.97 \pm 5.90^{\mathrm{a} \neq}$ \\
\hline C & $339.20 \pm 28.99^{\mathrm{a}^{*} \dagger \neq}$ & $129.80 \pm 72.05^{\mathrm{c}^{*} \neq \neq}$ & $34.27 \pm 21.51^{c^{*}+\neq}$ & $284.60 \pm 55.03^{a^{*} \dagger \neq}$ & $25.96 \pm 14.41^{b^{*}+\neq}$ \\
\hline $\mathrm{D}$ & $301.77 \pm 67.37^{c^{*} \neq}$ & $165.57 \pm 28.23^{b^{\star \star}}$ & $69.87 \pm 34.09^{a^{*} \neq}$ & $254.13 \pm 69.16^{\mathrm{b}^{*} \neq}$ & $33.65 \pm 5.65^{\mathrm{a}}$ \\
\hline LSD (0.05) & 0.002 & 0.18 & 0.266 & 0.017 & 0.18 \\
\hline
\end{tabular}

Values are expressed as Mean $\pm \mathrm{SD}, \mathrm{n}=4$.

Table 3: Effect of Solanum incanum on serum lipid profile of Wistar Albino Rats. 


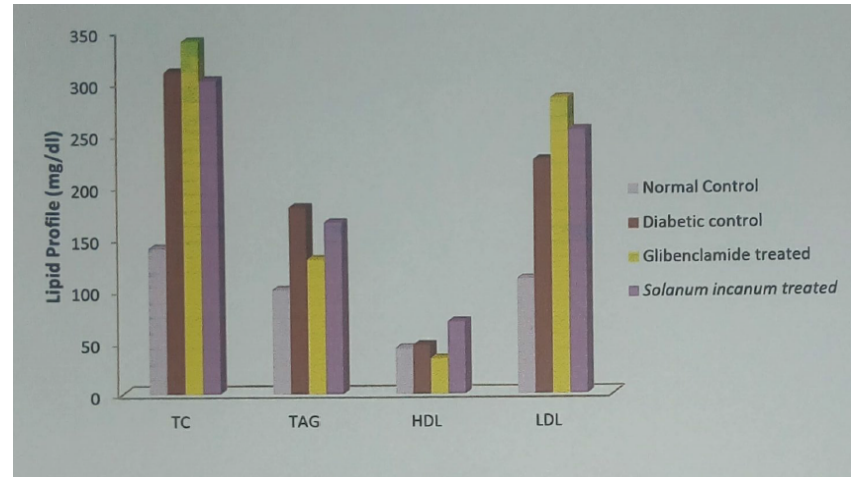

Figure 6: Effect of Solanum incanum on Serum lipid profile of Wistar Albino Rats.

diabetes in rats [43]. The loss of body weight could be due to dehydration and catabolism of fats and protein [44]. The improved $(\mathrm{P}<0.05)$ body weight obtained in this research is in agreement with the work of Ambika (2013) [45]. The increase $(\mathrm{P}<0.05)$ in body weight (Table 4) by the extract treated group may be due to increasing glucose uptake in peripheral tissues or inhibition of catabolism of fat and protein by good glycemic control [45,107-123].

From the results, the aqueous fruit extract of Solanum incanum can protect against hypercholesterolemia and hypertriglyceridemia. The mechanisms of its antilipidentic action may be related to its strong antioxidant, antilipidemia, and protection against endothelium dysfunction as also suggested by Arulmozhi [40].

\section{Conclusion}

In conclusion, the result of the present study shows that indeed the aqueous fruit extract of Solanum incanum reduced the raised TC, TAG and VLDL in alloxan induced diabetic Wistar Albino rats while increasing HDL and LDL levels in the same group of rats. These findings imply that aqueous fruit extract of Solanum incanum may have both antihypercholesterolemic and antihypertrigliceridemic effects. This observed hypolipidemic effect of Solanum incanum fruit in the co1Tection of dyslipidemia in alloxan-induced diabetic rats makes it beneficial in the dietary management of cardiovascular complications associated with diabetes and that its consumptions are safe for humans.

\section{Recommendations}

The following recommendations should be considered in subsequent research works: Research on the effect of Solanum incanum on lipid profile that will extend to 5th or 6th weeks of study period is required in order to observe adequate changes in the lipid profile of alloxan-induced diabetic Wistar Albino rats.

Research on the effect of Solanum incanum on lipid profile that will involve different doses should also be carried out in order to investigate the changes occurred if they are dose-dependent. Subsequent researches should also investigate the effect of the duration of acclimatization on the body weight of Wistar Albino rats as overweight may also pose an effect on lipid profile result.

I also recommend that further work need to be carried out to isolate and characterize the actual compound(s) responsible for the observed pharmacological activities. The direct or indirect effect of the extract on LDL oxidation, HMG CoA synthase, macrophages, NADPH oxidase or any superoxide generally enzymes which are involved in cholesterol metabolism must be investigated in order to confirm the actual mechanism(s) of action of Solanum incanum whether it is related to its strong antioxidant, antihyperlipidemic and protection against endothelium dysfunction.

\section{References}

1. Ozougwu JC, Obimba KC, Belonwu CD, Unakalamba CB (2013) The pathogenesis and pathophysiology of type $\mathrm{I}$ and type 2 diabetes mellitus. $\mathrm{J}$ Physiology and Pathophysiology 4: 46-57.

2. Arora S, Swadron SP, Dissanayake V (2010) Evaluating the Sensitivity of Visual Xanthochromia in patients with Subarachnoid hemorrhage. J Emerg Med 39: 13-16.

3. Mohammadi J, Saadipour K, Delaviz H, Mohammadi B (2011) Antidiabetic effects of an alcoholic extract of Jug/an s ragia in an animal model. Turk J Med Sci 41: 685-691.

4. VatsV, Yadav PS, Grover JK (2004) Ethanolic extract of Ocimum sanctum leaves partially attenuates streptozotocin-induced alterations in glycogen content and carbohydrate metabolism in rats. West Indian Med J 45: 60-62.

5. Kumar GPS, Arulselvan PD, Kumar DS, Subramanian SP (2006) Antibiotic activity of fruits of Terminalia chebula on streptozotocin induced diabetic rats. J Health Science 52: 283-291.

6. World Health Organization (2011) Global Health Estimates: Deaths by Cause Age, Sex, and Country.

7. King H, Aubert RE, Herman WH (1998) Global burden of diabetes, 19952025 Prevalence, numerical estimates and projections. Diabetes Care 21: 1414-1431.

8. Williams textbook of endocrinology (2011) Philadelphia: Elsevier/Saunders 1: 371-1435.

9. Szkudelski T (2001) The mechanism of alloxan and streptozotocin action P-cells of the rat pancrease. Physiol Res 50: 536-546.

10. Wild S, Roglica G, Green A, Sicree R, King H (2004) Global Prevalence of diabetes: Estimates for the year 2000 and Projections for 2030. Diabetes Care 27: 1047-1053.

11. Hu EA, Pan A, Malik V, Sun Q (2012) White rice consumption and risk of type 2 diabetes: meta-analysis and Systematic review. BMJ 34: e1454.

12. Okutan H, Ozcelik N, Yilmaz HR, Uz E (2005) Effects of caffeic acid phenethyl ester on lipid peroxidation and antioxidant enzymes in diabetic rat heart. Clin Biochem 38: 191-196.

13. Betteridge J (1997) Lipid Disorder in Diabetes Mellitus. In: Textbook of Diabetes. Blackwell Science PP: 1-55.

14. Tiwari AK, Rao JM (2002) Diabetes Mellitus and multiple therapeutic approaches of Phytochemicals: present status and future prospects. Curr Sci 83: $30-37$.

15. Irudayaraj SS, Sunil C, Duraipandiyan V, Ignacimuthu (2012) Anti diabetic and antioxidant activities of Toddalia asiatica (L) Lam. Leaves in streptozotocin induced diabetic rats. J Ethnopharmacol 143: 515- 523.

16. Okpara JO, Okpala EJ, Mamman M, Ayo JO, Cole TA (2007) Anti-diarrhoeal activity of the ethanolic extract of Adansonia digitata leaves. Vom J Vet Sci 1: 8-13.

17. Prasad, SK, Kulshrestha A, Qureshi (2009) Anti diabetic activity of some herbal plants in streptozotocin induced diabetic Albino rats. Pak J Nutr 8: 551-557.

18. Egede LE, Zheng D, Ye X, Silverstein MD (2002) The prevalence and pattern of complementary and alternative medicine use in individuals with diabetes. Diabetes Care 25: 324-329.

19. Yeh GY, Eisenberg DM, Kaptcuk TJ, Philips RS (2003) System review of herbs and dietary supplements for glycemic control in diabetes. Diab Care 26: 12771294.

20. Bnouham M, Ziyyat A, Mekhfi H, Tahri A, Legss A (2006) Medicinal plants with potential antidiabetic activity- $A$ review often years herbal medicine research. J Diab Metab 14: 1-25

21. Anosike CA, Obidoa O, Ezeanyika LU (2012) The anti-inflammatory activity of garden egg (Solanum aethiopicum) on egg albumin-induced oedema and granuloma tissue formation in rats. Asian Pac J Trop Med 5: 62-66.

22. Chinedu SN, Olasumbo AC, Eboji OK, Emiloju OC, Arinola OK, et al. (2011) Proximate and Phytochemical Analyses of Solanum aethiopicum $\mathrm{L}$ and Solanum macrocarpon L. Fruits Res J Chem Sci 1: 63-71. 
Citation: Tsenum JL (2018) Antihyperlipidemic Effect of Solanum incanum on Alloxan Induced Diabetic Wistar Albino Rats. Cardiovasc Pharm Open Access 7: 239. doi: 10.4172/2329-6607.1000239

23. Dalal S, Beunza JJ, Volmink J, Adebamowo C, Bajunirwe F, et al. (2011) Non-communicable diseases in sub-Saharan Africa: what we know now. Int $\mathrm{J}$ Epidemiol 40: 885-901.

24. Kapiga S (2011) Commentary: Non-communicable diseases in sub-Saharan Africa: a new global health priority and opportunity. Int J Epidemiol 40: 902-903.

25. Negin J, Cumming R, De Ramirez SS, Abimbola S, Sachs SE (2011) Risk factors for non-communicable diseases among older adults in rural Africa. Trap Med Int Health 16: 640-646.

26. Katsumata K, Katswnata Y, Ozawa T, Katsumata J (1993) Potentiating effects of combined usage of three sulfonylurea drugs on the occurrence of alloxan diabetes in rats. Harm Metab Res 25: 125-126.

27. Dhandapani S, Subramanian VR, Rajagopal, Namasivayam N (2002) Hypolipidemic effect of Cuminum cyminum $L$ on alloxan induced diabetic rats. Pharmacol Res 46: 251-255.

28. America Diabetes Association (2010) Diagnosis and classification of diabetes mellitus. Diabetes Care 33: 62-69.

29. Friedewald WT, Levy RI, Fredrickson DS (1972) Estimation of the concentration of low-density lipoprotein cholesterol in plasma, without use of the preparative ultracentri fuge. Clinical Chem 18: 499-502.

30. Durrington $P$ (2003) DysUpida emia. Lancet 362: 717-731.

31. Arvind K, Pradeepa R, Deepa R, Mohan V (2002) Diabetes and coronary artery diseases. Indian J Med Res 116: 163-176.

32. O’ Brien T, Nguyen TT, Zimmerman BR (1998) Mayo Clin Proc. 78: 969-976.

33. McKenney JM, McCormick LS, Schaefer EJ, Black DM, Watkins ML (2001) Effect of niacin and atorvastatin on lipoprotein subclasses in patients with atherogenic dyslipidemia. Am J Cardiol 88: 270-274.

34. Raghuveer, Choudhary (2008) Beneficial effect of allium sativum and al/ium tuberosum on experimental hyperlipidemia and atherosclerosis. Pakistan J Physiology 4: 7-9.

35. Brown AS, Bakker, Arkema RG, Yellen L (1998) Treating patients with documented atherosclerosis to National Cholesterol Education Program recommended low density lipoprotein cholesterol goals with atorvastatin, fluvastatin, lovastatin and simvastatin. J Molecular Cellular Cardiology 32: 665-692.

36. Gandhi GR, Lgnacimuthu S, Paulraj MG (2011) Solanum torvum Swa11z. Fruit containing phenolic compounds shows antidiabetic and antioxidant effects in streptozotocin induced diabetic rats. Food Chem Toxicol 49: 2725-2733.

37. Danilova LG, Sarapultsev PA, Medvedeva SU, Gette IF, Bulavintceva TS, et al. (2014) Morphological Restructuring of myocardium During the Early Phase of experimental Diabetes Mellitus. Anat Rec.

38. Auta R, Ali I (2011) Nutritional and Chemical Evaluation of Solanum incanum (Bitter garden egg). Int J Tropical Medicine and Public Health 1: 96-107.

39. Chinedu SN, Okwuchukwu K, Eboji, Solomon OR (2013) Effects of Solanum aethiopicum Fruit on Plasma Lipid Profile inrats. Adv Biores 4: 79-84.

40. Arulmozhi V, Krishnaveni M, Karthishwaran K, Dhamodharan G, Mirunalini S (2010) Antioxidant and antihyperlipidemic effect of Solanum nigrum fruit extract on the experimental model against chronic ethanol toxicity. Phcog Mag 6: 42-50.

41. Al-Shamaony L, Al-Khazraji, Twaiji (1994) Hypoglycemic effect of Artemisiaherbaalba Effect of a valuable extract on some blood parameters in diabetic animals. J Ethnopharmacol 43: 167-171.

42. Sharma SR, Dwivedi SK (1997) Hypoglycaemic, antihyperglycaemic and hypolipidemic activities of Cesa/pinia bounducel/a seed in rats. J Ethnopharmacol 58: 39-44.

43. Ramachandran S, Naveen KR, Rajinikanth B, Akbar M, Rajasekaran (2012) Antidiabetic, antihyperlipidemic and in vivo antioxidant potential of aqueous extract of Anogiessus latifolia bark in type 2 diabetic rats. Asian Pac J Trap Dis 231: $596-602$.

44. Rajkumar L, Govidarajula P, Srinivasan N, Balasubramanian K (1991) Increased degredation of dermal collagen in diabetic rats. Indian $\mathrm{J}$ Exp Biol 29: 1081-1083.

45. Ambika S, Saravanan R, Thirumavalavan (2013) Antidiabetic and antihyperlipidemic effect of p-hydroxycinnamic acid on streptozotocin induced diabetic wistar rats. Biomed. Aging Pathol 3: 253-257.

46. Abbiw A (1990) Plants of Ghana. Intermediate technology Southampton, London.
47. Abrass CK (2004) Cellular lipid metabolism and the role of lipids in Progressive renal disease. Am J Nephrology 24: 46-53.

48. Ahmed I, Lakhani MS, Gillett M, John A, Raza H (2001) Hypotriglyceridemic and hypocholesterolemic effects of anti-diabetic Momordica charantia (karela) fruit extract in streptozotocin- induced Diabetic rats. Diabetes Res Clin Pract 51: 155-161.

49. Aliyu HM (2006) Proximate Analysis of Some Leafy Vegetables' (Roselle Jute And Bitter Leaf). Int J Food Agricultural Resources 3: p112.

50. Amadi JE, Salami SO, Eze CS (2010) Antifungal properties and phytochemical screening of extracts of African Basil (Ocimum gratissimumL). Agric Biol J N Am 1: 163-166.

51. http://www.1abtestsonline.org/understanding/analytes/lipid/tab/test/

52. American Diabetes Association (2001) Gestational diabetesmellitus. Diabetes Care 24: 5-19

53. American Diabetes Association (2010) Standards of medical care in diabetes. Diabetes Care 33: 11-61.

54. American Diabetes Association (2011) Standards of Medical Care in Diabetes Diabetes Care 34: 11-6I.

55. American Diabetes Association (2014) Standards of Medical Care in Diabetes Diabetes Care 37: 14-80.

56. Anwa EP, Auta J, Abdullahi SA, Boloruduro PI (2007) Effects of processing on seeds of Albizzia lebbeck: Proximate analysis and phytochemical screening Res J Biolog Scie 2: 41-44.

57. Balandrin MF, Kjocke AJ (1985) Natural Pla nt chemicals sources of industria and materials Sciences. 228: 1154-1160.

58. Balandrin MF (1996) Commercial Utilization of Plant-derived Soponins: An Overview of medicinal. Pharmaceutical and Industrial Applications. Soponins Used in Traditional and Modern Medicine PP: I-14.

59. Bari MA, Islam LW, Khan AR (20 I 0) Antibacterial and Antifungal Activity of Solanum thorium.

60. Beaman-Mbaya V, Muhammed SI (1976) Antibiotic action of Solanum incanum Antimicrob Agents Chemother 9: 910-924.

61. Bedoya FJ, Solano F, Lucas M (1996) N-Monomethyl-arginine and nicotinamide prevent streptozotocin-induced double strand DNA break formation in pancreatic rat islets. Cellular and molecular Life Sciences 52: 344-347.

62. Burkill HM (2000) The useful plants of West Africa 5, Families S-Z, Addenda Royal Botanic Gardens, Kew, Richmond, United Kingdom P: 686.

63. Chan LW, Cheah ELC, Saw CLL, Weng W, Heng PWS (2008) Antimicrobial and antioxidant activities of Cortex Magnoliae Officinalis and some other medicinal plants commonly used in South-East Asia. China Med 3: 15.

64. Chukwuma ER, Obioma N, Christopher OL (2010) The Phytochemical composition and some biochemical effects of Nigerian Tigernut (Cyperus esculentus L.) Tuber. Pakistan J Nutrition 7: 709-715.

65. Cooke D, Plotnick L (2008) Type 1 diabetes mellitus in pediatrics. Pediatr Rev 29: 374-384.

66. Coppack S, Jensen M, Miles J (1994) In vivo regulation of lipolysis in humans J Lipid Res 35: 177-193.

67. Delaney CA, Dunger A, Di Matteo M, Cunningham JM, Green MH, et al. (1995) Comparison of inhibition of glucose-stimulated insulin secretion in rat islets of Langerhans by Streptozotocin and methyl and ethyl nitrosoureas and methanesulphonates: Lack of correlation with nitric oxide-releasing or O6alkylating ability. Biochem Pharmacol 50: 2015-2020.

68. Denston TC (1951). A textbook of Pharmacology medicinal plants of West Africa. London Oxford Press 147-149.

69. Deruiter J (2003) Overview of the antidiabetic agents. Endocrine Pharmacotherapy Module PP: I-33.

70. Dheer R, Bhatnagar P (2010) A study of the antidiabetic activity of Barleria prionitis Linn. Indian J Pharmacol 42: 70-73.

71. Eizirik DL, Pipeleers DG, Ling Z, Welsh N, Hellerstrom C, et al. (1994) Major species differences between humans and rodents in the susceptibility to pancreatic beta-cell injury. Proc Natl Acad Sci USA 91: 9253-9256. 
Citation: Tsenum JL (2018) Antihyperlipidemic Effect of Solanum incanum on Alloxan Induced Diabetic Wistar Albino Rats. Cardiovasc Pharm Open Access 7: 239. doi: 10.4172/2329-6607.1000239

Page 8 of 9

72. Elsner M, Guldbakke B, Tiedge M, Munday R, Lenzen S (2000) Relative importance of transport and alkylation for pancreatic beta cell toxicity of streptozotocin. Diabetologia 43: 1528-1533.

73. Gruppuso PA, Boylan JM, Posner BI, Faure R, Brautigan DL (1990) Hepatic protein phosphotyrosine phosphatase. Dephosphorylation of insulin receptor and epidermal growth factor receptors in normal and alloxan diabetic rats. $J$ Clin Invest 85: 1754-1760.

74. Hikino H, Kobayashi M, Suzuki Y, Konno C (1989) Mechanisms of hypoglycemic activity of aconitan A, a glycan from Aconitum carmichaeli roots. J Ethnopharmacol 25: 295-304.

75. Holmgren AV, Wenner W (1952) Alloxan monoh hydrate. Org Synth 32: 23.

76. Hsieh CC, Fang HL, Lina WC (2008) Inhibitory effect of Solanum nigrum on thioacetamide induced liver fibrosis in mice. J Ethnopharmacol 119: 117-121.

77. Hu FB (2011) Globalization of Diabetes: The role of diet, lifestyle and genes. Diabetes Care. 34: 1249-1257.

78. Ikeda T, Tsumagari H, Nohara T (1978) Steroidal Oligoglycosides from Solanum nigrum growing in Azerbaijan. Chem Pharm Bull (Tokyo) 48: 10621064.

79. Jainu M, Shyamala Devi CS (2004) Antioxidant effect of methanolic extract of Solanum nigrum berries on aspirin induced gastric mucosa! Injury. Indian JC/ in Biochem 19: 57-61.

80. John Britto S, Senthil kumar S (2001) Antibacterial activity of Solanum incanum L. leaf extracts. Asian J Microbiol Biotechnol Environ Sci 3: 65-66.

81. Jung UJ, Park YB, Kim SR, Choi MS (2012) Supplementation of persimmon leaf ameliorates hyperglycemia, dyslipidemia and hepatic fat accumulation in type 2 diabetic mice. PloS One 7: e49030.

82. Kameswara RB, Guiri Kesavulu MM, Apparao CH (2001) Effect of oral administration of bark extracts of Pterocarpus santalinus $L$. on blood glucose level in experimental animals. J Ethnopharmacol 74: 69-74.

83. Kang ralkar VA, Patil SD, Bandivadekar RM (2010) Oxidative Stress and Diabetes: A Review. Int J Pharm Appl 38-45.

84. Katalinic V, Milos M, Kulisic T, Jukic M (2006) Screening of 70 Medicinal plant extracts for antioxidant capacity and total phenols. Food Chemistry 94: 550557.

85. Kiselova Y, Ivanova D, Chervenkov T, Gerova D, Galunska B, et al. (2006) Correlation between the invitro antioxidant activity and Polyphenol content of aqueous extracts from Bulgarian herbs. Phytotherapy Research 20: 961-965.

86. Krisharaju AV, Rao TVN, Sundararaju D, Vanisree M, Tsay HS, et al. (2005) Assessment of bioactivity of Indian medicinal plants using Brine shrimp (Altenaria salania) lethality assay. Int J Appl Sci Eng 2: 125-134.

87. Kumar VP, Shashidra S, Kumar MM, Shridhara BY (2001) Cytoprotective role of Solanum nigrum against gentamycin induced kidney cell (Vero Cells) damage in vitro. Fitoterapia 72: 481-486.

88. Lee IM, Shiroma EJ, Lobelo F, Puska P, Blair SN, et al. (2012) Effects of physical inactivity on major non-communicable diseases worldwide: an analysis of burden of disease and life expectancy. Lancet 380: 219-29.

89. Lenzen S (2008) The Machanisms of alloxan and Streptozotocin-Induced Diabetes. Diabetologia 5I: 216-226.

90. Lin HM, Tseng HC, Wang CJ, Lin JJ, Lo CW, et al. (2008) Hepatoprotective Effects of Solanum nigrum Linn extract against $\mathrm{CCl} 4$ induced oxidative damage in rats. Chemico Biol Interact 171: 283-93.

91. Loreto D, Elina V (2009) Experimental Surgical models in the laboratory rat Boca Raton: CRC Press.

92. Luna B, Fienglos MN (2001) Oral agents in the management of type 2 diabetes mellitus. Am Fam Phy 63: 1747-1756.

93. Malik VS, Popkin BM, Bray GA, Despres JP, Hu FB (2010) Sugar Sweetened Beverages, Obesity and Type 2 diabetes and Diabetes and cardiovascular Disease risk. Circulation 121: 1356-64.

94. Mitchell J (1962) Medicinal plants and their constituents. University press Cambridge, UK.

95. Nam SH, Kang MY (2004) Antioxidant activity of 13 medicinal plants. Pharmaceutical Biology 42: 409-415.

96. Nathan DM, Cleary PA, Backlund JY, Genuth SM, Lachin JM, et al. (2005) Intensive diabetes treatment and cardiovascular disease in patients with type I diabetes. The New England J Med 353: 2643-53.

97. National Diabetes Clearinghouse (NDIC) (2011) National Diabetes Statistics U.S Department of Health and Human and Human Services.

98. Patil S, Joshi V, Sutar P, Sambrekar S (2009) Screening of whole plant extract of Solanum surattense for antibacterial activity. Inter J Pharmaceutical Sci 1 : 110-114.

99. Patlak M (2002) New weapons to combat an ancient disease: treating diabetes The FASEB J 16: 1853.

100. Pavitra PS, Janani VS, Charumathi KH, Indumathy R, Sirisha P, et al. (2012 ) Antibacterial activity of plants used in indian herbal medicine. Inter J Green Pharmacy 23-28.

101.Pengery A (2004) Constituents of medicinal plants: Introduction to the Chemistry and therapeutics of herbal medicine. CAB International USA.

102.Perez RM, Perez JA, Garcia LM, Sossa M (1998) Neurophannacological activity of Solanum nigrum fruit. J Ethnopharmacol 62: 43-8.

103. Poretsky L, Song L, Brillon DJ, Ferrando S, Sison C, et al. (2009) Metabolic and Hormonal Effects of Oral DHEA in premenopausal women with HIV infection. Hormonal and Metabolic Research 41: 244-249.

104. Potawel SE, Sinha SD, Shroff KK, Dhalawat HJ, Boraste SS, et al. (2008) Solanum nigrum Linn: A Phytochemical Review. Pharmacology 3: 140-63.

105. Raju K, Anbuganapathy G, Gokulakrishnan V, Rajkapoor B, Jayakar B, et al. (2003). Effect of dried fruits of Solanum Linn against CCl4 induced hepatic damage in rats. Biol Pharm Bui 26: 1618-9.

106. Rani P, Khullar N (2004) Antimicrobial evaluation of some medicinal plants for their anticentric potential against multidrng resistant. Phytother Res 18: 670-3.

107. Ripoll BC, Ignacio L (2011). Exercise and disease management (2nd edn), Boca Raton: CRC Press.

108. Riserus U, Willet WC, Hu FB (2009) Dietary fats and prevention of type 2 diabetes. Progress in Lipid Research 48: 44-51.

109. Rother KI (2007) Diabetes treatment-bridging the divide. The New England $J$ Med 356 (15): 1499-501.

110. Sandhir R, Gill KD (1999) Hepatoprotective effects of Liv52 on ethanol induced liver damage in rats. Indian J Exp Biol 37: 762-6.

111. Sarwar N, Gao P, Seshasai SR, Gobin R, Kaptoge S, et al. (2010) Diabetes mellitus, fasting blood glucose concentration, and the risk of vascular disease: A collaborative meta analysis of 102 prospective studies. The Lancet 375 : 2215-22.

112. Sattar N, Preiss D, Murray HM, Welsh P, Buckley BM, et al. (2010) Stalins and risk of incident diabetes: a collaborative meta-analysis of randomized statin trials. The Lancet 375: 735-42.

113. Sharma SB, Tanwar RS, Nasir A, Prabhu (2011). Antihyperlipidemic effect of active principle isolate from seed of Eugenia janbolana on alloxan induced diabetic rabbits. J Med Food 14: 353-359.

114. Sheeba E (2010) Antibacterial activity of Solanum surattense Burm. F. Kathamandu University Journal of science, Engineering and Technology 6: 1-4.

115. Sridhar TM, Josthna P, Naidu CV (20I I) In Vitro Antibacterial Activity and Phytochemical Analysis of Solanum nigrum (Linn.): An Important Antiulcer Medicinal Plant. J Experi Sci 2: 24-29.

116. Sumana G, Suryawarshi SA (2001) Effect of Vinca rosea extracts in treatment of streptozotocin diabetes in male albino rats. Indian J Exper Bio 9: 748-758.

117. Tariq Al-Qirim, Syed MZ, Moyad S, Ghassan S, Naheed B (2008) Effect of Solanum nigrum on immobilization stress induced antioxidant defence changes in rat. Res J Biol Sci 3: 1426-9.

118. Tipson RS (1953) Alloxantin dihydrate. Org Synth 33: 325.

119. Vidhya G, Anuradha R (2014) Hypoglycaemic Effect of Cassia auriculata Linn: Flowers on Streptozotocin Induced Male Albino Rats. Inter J Phytopharma 5: 323-327.

120.Von Mehring J, Minkowski O (1890) Diabetes mellitus nach pancreas exstirpation. Arch Exp Pathol Pharmakol 26: 371-387.

121. Willi C, Bodenmann P, Ghali WA, Faris PD, Cornuz J (2007) Active smoking and the risk of type 2 diabetes: A systematic review and meta analysis. JAMA: The J the Am Medical Assoc 298: 2654-64 
Citation: Tsenum JL (2018) Antihyperlipidemic Effect of Solanum incanum on Alloxan Induced Diabetic Wistar Albino Rats. Cardiovasc Pharm Open Access 7: 239. doi: 10.4172/2329-6607.1000239

Page 9 of 9

122. World Health Organization (2013) Diabetes Fact sheet $N^{\circ} 312$. World Health Organisation. (2014). Diabetes Programme.
123.Zakaria ZA, Gopalan HM, Zainal H, Mohd NH, Morsid NA, et al. (2006) Antinociceptive, Anti-inflammatory and Antipyreticeffects of Solanum nigrum Chloroform extract in animal models. Pharma Soci Jpn 126: 1171-8. 


\section{APPENDIX}

Table 4.1: Stutistieal Analysis of Trentment with Solanum Incamum Extract on

Fasting Plasma Glucose Level of Alloxan-Induced Dinbetic Wistar Albino

Ruts

\begin{tabular}{|c|c|c|c|c|}
\hline Treatment & $\begin{array}{l}\text { Before } \\
\text { Induction } \\
\text { (mg/dl) }\end{array}$ & $\begin{array}{l}72 \text { Hours After Induction } \\
\qquad \text { (mg/dl) }\end{array}$ & $\begin{array}{l}1 \mathrm{WAT} \\
\text { (mg/dl) }\end{array}$ & $\begin{array}{l}2 \text { WAT } \\
\text { (mg/dl) }\end{array}$ \\
\hline A & $75.67 \pm 3.06^{\mathrm{n}}$ & $114.00 \pm 10.82^{n}$ & $94.00 \pm 3.61^{\circ}$ & $81.67 \pm 19.35^{b}$ \\
\hline B & $78.66 \pm 4.04^{\prime \prime}$ & $137.67 \pm 10.07^{\prime \prime}$ & $110.67 \pm 7.02^{n 4}$ & $82.67 \pm 3.79^{b}$ \\
\hline C & $73.33 \pm 2.08^{n}$ & $134.67 \pm 16.56^{\mathrm{n}}$ & $106.00 \pm 2.00^{14}$ & $90.67 \pm 17.47^{n^{*}}+\phi$ \\
\hline D & $73.67 \pm 3.26^{\mathrm{a}}$ & $133.67 \pm 15.56^{\prime \prime}$ & $102.00 \pm 1.00^{4}$ & $78.67 \pm 6.11^{b}$ \\
\hline LSD (0.05) & 0.154 & 0.982 & 0.006 & 0.737 \\
\hline
\end{tabular}


Table 4.2: Statistical Analysis of Treatment with Solanum Incanum Extract on Body Weight of Alloxan-Induced Diabetic Wistar Albino Rats

\begin{tabular}{lcc}
\hline Treatment & 1 WAT & 2 WAT \\
& $(\mathrm{g})$ & $(\mathrm{g})$ \\
\hline A & $137.00 \pm 24.19^{\mathrm{c}}$ & $140.33 \pm 8.50^{\mathrm{d}}$ \\
B & $200.00 \pm 6.25^{\mathrm{b}}$ & $199.67 \pm 24.68^{\mathrm{b}} \neq$ \\
C & $200.00 \pm 20.88^{\mathrm{b}} \dagger \neq$ & $193.00 \pm 19.08^{\mathrm{c}^{*}} \uparrow \neq$ \\
D & $205.00 \pm 17.52^{\mathrm{a}^{\mathrm{a}^{*}} \neq}$ & $218.00 \pm 13.08^{\mathrm{a}^{*}} \ddagger$ \\
LSD (0.05) & 0.06 & 0.03 \\
\hline
\end{tabular}

Table 4.3: Statistical Analysis of Treatment with Solanum Incanum Extract on Fasting Serum Lipid Profile of Alloxan-Induced Diabetic Wistar Albino Rats

\begin{tabular}{|c|c|c|c|c|c|}
\hline Treatment & $\begin{array}{c}\mathrm{TC} \\
(\mathrm{mg} / \mathrm{dl})\end{array}$ & $\begin{array}{c}\text { TAG } \\
(\mathrm{mg} / \mathrm{dl})\end{array}$ & $\begin{array}{c}\text { HDL } \\
(\mathrm{mg} / \mathrm{dl})\end{array}$ & $\begin{array}{c}\text { LDL } \\
(\mathrm{mg} / \mathrm{dl})\end{array}$ & $\begin{array}{l}\text { VLDL } \\
\text { (mg/dl) }\end{array}$ \\
\hline A & $140.37 \pm 26.65^{\mathrm{d}}$ & $100.50 \pm 26.96^{\mathrm{d}}$ & $44.43 \pm 4.33^{b}$ & $111.33 \pm 21.57^{\mathrm{d}}$ & $20.10 \pm 5.39^{c}$ \\
\hline B & $309.80 \pm 39.17^{\mathrm{b}} \neq$ & $179.87 \pm 29.50^{\mathrm{a}} \neq$ & $47.07 \pm 7.69^{b}$ & $225.77 \pm 58.17^{c} \neq$ & $35.97 \pm 5.90^{\mathrm{a}}$ \\
\hline $\mathrm{C}$ & $339.20 \pm 28.99^{\mathrm{a}^{*}} \dagger \neq$ & $129.80 \pm 72.05^{\mathrm{c}^{*}} \dagger \neq$ & $34.27 \pm 21.51^{c^{*}} \dagger \neq$ & $284.60 \pm 55.03^{\mathrm{a}^{*}} \dagger \neq$ & $25.96 \pm 14.41^{\mathrm{b}}$ \\
\hline D & $301.77 \pm 67.37^{c^{*}} \ddagger$ & $165.57 \pm 28.23^{\mathrm{b}^{*}} \ddagger$ & $69.87 \pm 34.09^{\mathrm{a}^{*}} \ddagger$ & $254.13 \pm 69.16^{b^{*}} \ddagger$ & $33.65 \pm 5.65^{\mathrm{a}}$ \\
\hline LSD (0.05) & 0.002 & 0.180 & 0.266 & 0.017 & 0.180 \\
\hline
\end{tabular}




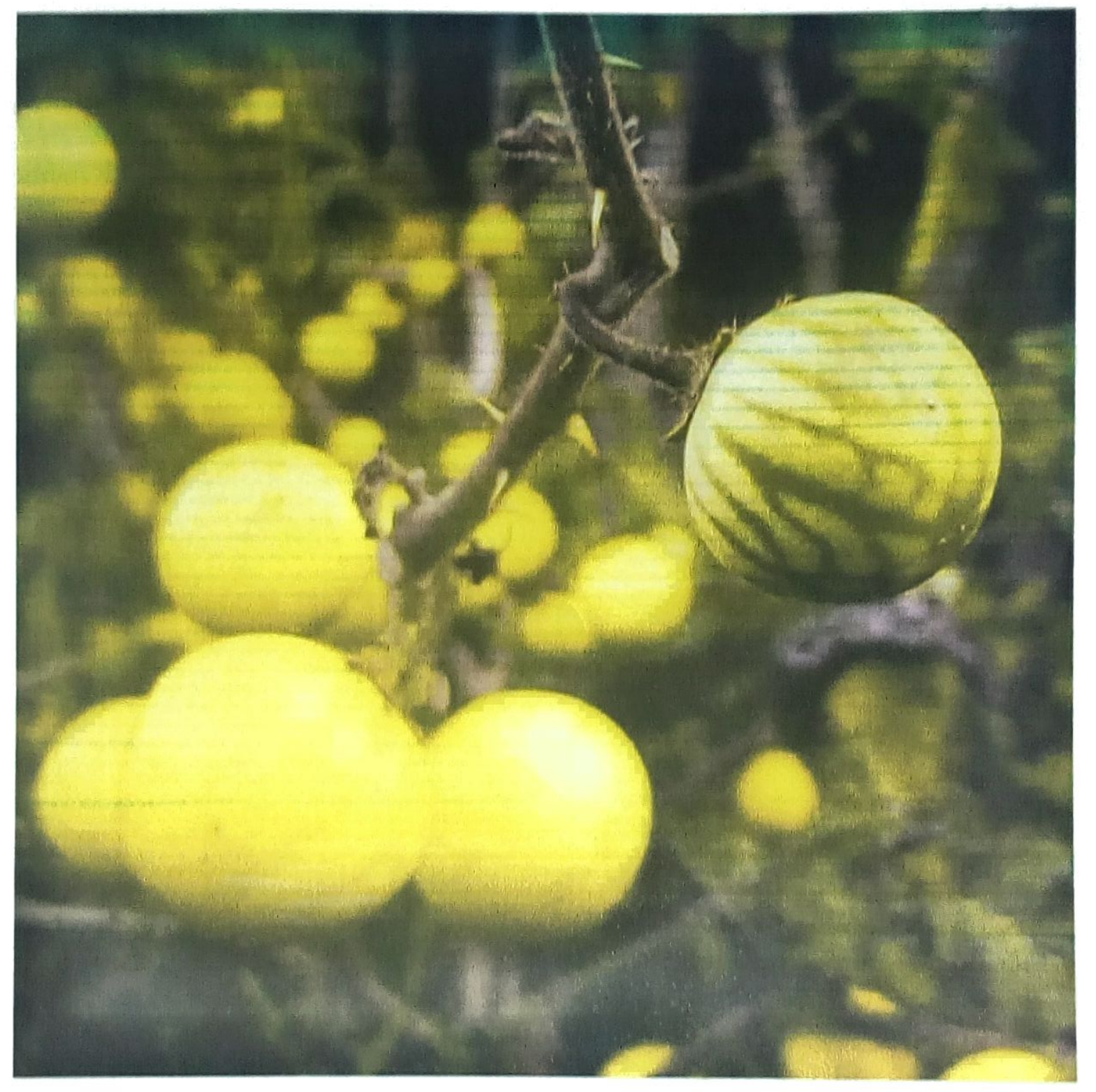

Figure 1.1: Bitter garden egg (Solanum incanum) 

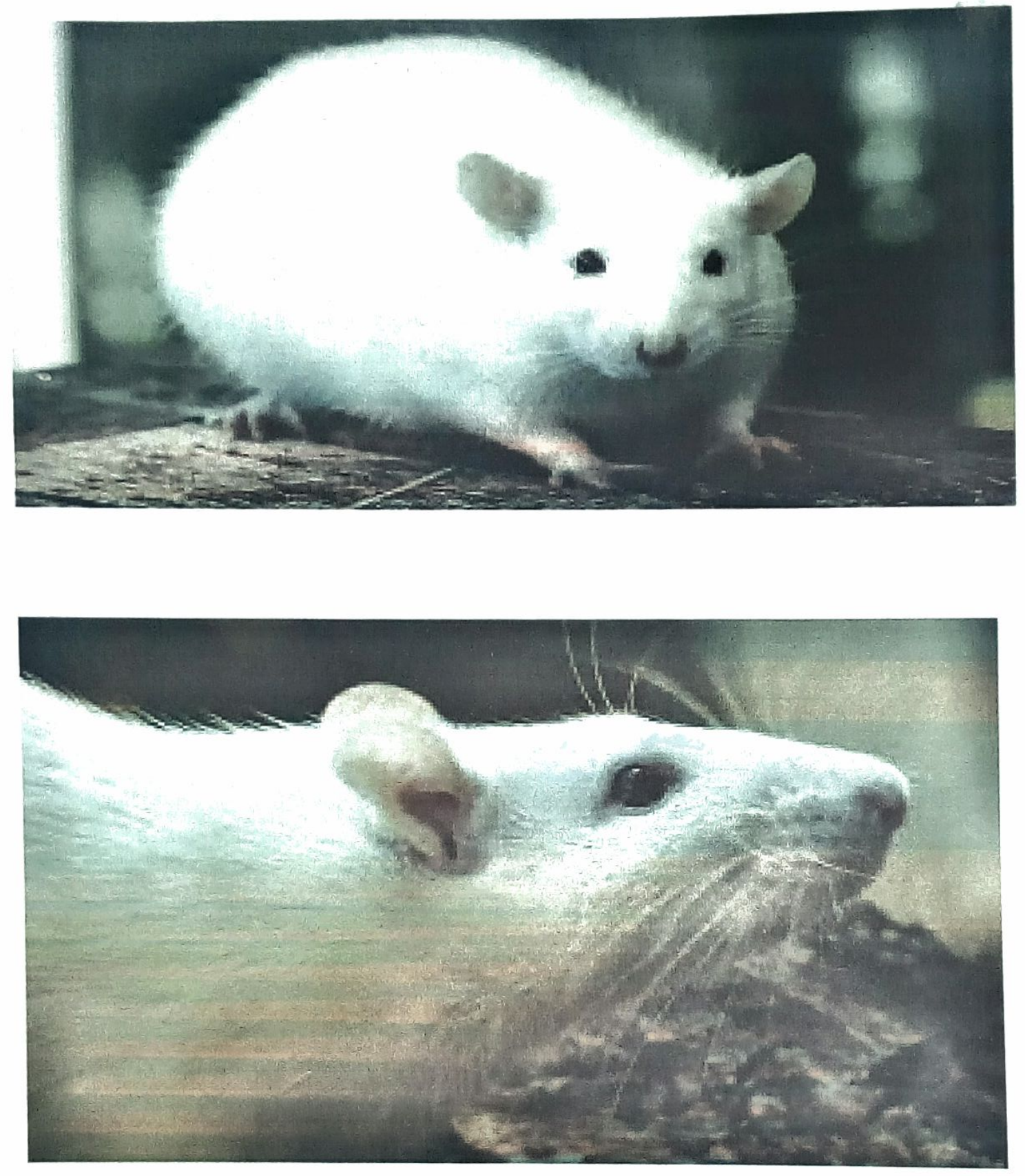

Figure 3.1: Wistar Albino Rats 


\section{Lipid Profile formulars}

Triacylglycerol $(\mathrm{mg} / \mathrm{dl})=$ Absorbance of sample $\quad \times$ Concentration of Standard $(\mathrm{mg} / \mathrm{dl})$

Absorbance of standard

Total cholesterol $(\mathrm{mg} / \mathrm{dl})=$ Absorbance of sample $\times$ Concentration of Standard $(\mathrm{mg} / \mathrm{dl})$

Absorbance of Standard

HDL Cholesterol $(\mathbf{m g} / \mathrm{dl})=$ Absorbance of sample $\times \mathrm{N} \times 2$

Absorbance of standard

Where, $2=$ dilution factor of the sample, $N=$ standard concentration

LDL Cholesterol $(\mathbf{m g} / \mathbf{d l})=$ Total Cholesterol $-($ HDL Cholesterol + Triacylglycerides/5)

VLDL Cholesterol $=$ Triacylglycerides $/ 5$. 